\title{
A Review of Recent Civil Air Transport Accidents/ Incidents and Their Fire Safety Implications
}

\author{
RICHARD G. HILL \\ Fire Safety Branch \\ Federal Aviation Administration Technical Center \\ Atlantic City International Airport, New Jersey 08405 \\ U.S.A.
}

\begin{abstract}
This paper presents a brief summary of recent civil air transport accidents and major incidents involving fire. It updates the paper "Investigation and Characteristics of Major Fire Related Accidents in Civil Air Transports Over the Past Ten Years"1. A more detailed review of selected accidents/incidents is presented including their link to safety improvements made todate in fire resistant materials and their impact on improved passenger survivability and the need for improvements in aircraft systems, such as oxygen, hydraulic and electrical, to further improve survivability. Research and Development to reduce aircraft fire fatalities is discussed and justified using accident/incident data. The paper discusses the problem of Halon replacement. Accident/incident data is used to show the need to choose replacement agents that can perform well against real aircraft fires. The need for realistic test methods is discussed. The paper concludes that additional improvements in passenger fire survivability are needed and attainable.
\end{abstract}

\section{INTRODUCTION}

Over the past several years the Federal Aviation Administration (FAA) and most other aviation authorities worldwide have implemented numerous modifications to aircraft fire safety standards. Those modifications have vastly improved fire safety in transport aviation. Those modifications include the following:

The Seat Cushion "Fire Blocking" Rule. This rule requires that all cabin seat cushions in transport aircraft meet a large oil burner test. The result of this rule change was that most seat cushions were "fire blocked". The term fire blocking refers to encapsulating the foam with a very fire resistant material. The fire blocker is usually over urethane foam and under the outer dress cover. The fire blocking materials presently available cannot be dyed. Therefore, they are not used as outer covers. Until recently, urethane foam, the only foam meeting airline requirements, could not be made fire resistant enough without a large, and unacceptable, increase in weight. The effects of this rule have been documented in accident investigations 
and in one case, Delta 727 in Dallas, Texas, August 31, 1988, it was cited by investigators as having provided a longer evacuation time, thus, saving many lives.

Floor Level Lighting Rule. This is a requirement for emergency lighting near the floor in an aircraft. As a result, most airlines have installed floor track lighting (light strips on the floor).

Low Heat/Smoke Release Panel Rule. This is a requirement for the large surface material in an aircraft cabin (ceiling, sidewall, stowage bins, partitions, etc.), and is required for newly manufactured or totally refurbished aircraft. This is also referred to as the "OSU Rule" because of the test method required. This rule forced the airframe manufacturers to upgrade most of the materials used in aircraft interiors.

Cabin Fire Extinguisher Rule. A requirement of transport aircraft to carry at least two Halon 1211 extinguishers. This requirement may have resulted in saving a Delta L1011 from a catastrophic inflight fire over the North Atlantic during March 1991.

Lavatory Smoke Detection/Extinguishment Rule. This rule requires smoke detectors in all transport aircraft lavatories as well as a fixed extinguisher (known as a potty bottle) in all lavatory trash receptacles. The main job of these systems is the protection against smokers in the lavatory.

Radiant Heat Resistant Evacuation Slide Requirement. This was a change to the Technical Standard Order (TSO) that contained the requirements for the emergency evacuation slides. The change incorporated a radiant heat test for slide material designed to improve the ability of the slide to resist the heat from a large fuel fire nearby.

Cargo Compartment Rules. There have been three major rule changes effecting cargo compartments on transport category aircraft. The first was a change to newly certificated aircraft only. It reduced the allowable size of a class " $\mathrm{D}$ " compartment to 1000 cubic feet, and imposed a new test method for cargo liners, seams, joints, and fastening systems. The second rule change was a retroactive rule requiring the modification of class " $C$ " and " $D$ "

compartments. This rule has lead to the removal of Kevlar and Nomex liners, the redesign of some fixtures and fastening systems, and new methods for patching damaged liners. The third rule change was an $\mathrm{AD}$ changing the requirements for class " $\mathrm{B}$ " (Combi) compartments.

It should be noted that the greatest improvements in fire safety have been gained in the area of materials flammability upgrading.

Safety improvements are judged by their expected benefit versus their cost. Since future benefit is most often based on past accident experience, it is very important to have enough information about past accidents as a basis for that judgment. In evaluating a safety improvement, a wide range of accident scenarios must be studied, making sure that improvement in some scenarios is not a detriment in others. 
TABLE 1

Civil Transport Aircraft Accidents (1987-1992) with Fire-Related Deaths or Destruction of the Aircraft By Fire

\begin{tabular}{|c|c|c|c|c|c|}
\hline Date & Carrier & $\begin{array}{l}\text { Place of } \\
\text { Accident }\end{array}$ & $\begin{array}{l}\text { Type of } \\
\text { Aircraft }\end{array}$ & $\begin{array}{l}\text { Number of } \\
\text { Occupants }\end{array}$ & $\begin{array}{l}\text { Number of } \\
\text { Fatalities }\end{array}$ \\
\hline 1. $4 / \mathrm{Apr} / 87$ & Garuda & Medan & DC-9 & 45 & 28 \\
\hline 2. 5/Aug/87 & Lan Chile & Santiago & B-737 & 33 & 2 \\
\hline 3. $16 / \mathrm{Aug} / 87$ & Northwest & Detroit & DC-9 & 155 & 154 \\
\hline 4. $15 /$ Nov $/ 87$ & Continental & Denver & DC-9 & 82 & 28 \\
\hline 5. $28 / \mathrm{Nov} / 87$ & South African & Indian Ocean & B-747 & 161 & 161 \\
\hline 6. $26 / \mathrm{Jun} / 88$ & Air France & Habsheim & A-320 & 136 & 3 \\
\hline 7. $31 / \mathrm{Aug} / 88$ & Delta & Dallas & B-727 & 108 & 14 \\
\hline 8. $15 / \mathrm{Sep} / 88$ & Ethiopian & Bahir, Dar & B-737 & 104 & 35 \\
\hline 9. $17 / \mathrm{Oct} / 88$ & Uganda & Rome & B-707 & 57 & 32 \\
\hline $10.25 /$ Oct $/ 88$ & Aero Peru & Juliaca & $F-28$ & 89 & 12 \\
\hline 11. $3 / \mathrm{Feb} / 89$ & Burma & Rangoon & $F-27$ & 28 & 26 \\
\hline 12. $10 / \mathrm{Mar} / 89$ & Air Ontario & Dryden & F-28 & 86 & 24 \\
\hline 13. 19/Jul/89 & United & Sioux City & DC- 10 & 286 & 111 \\
\hline 14. $14 / \mathrm{Feb} / 90$ & Indian & Bangalore & A-320 & 146 & 92 \\
\hline 15. 11/May/90 & Philippines & Manila & B-737 & 119 & 8 \\
\hline 16. $3 / \mathrm{Dec} / 90$ & Northwest & Detroit & DC-9 & 44 & 8 \\
\hline 17. $1 / \mathrm{Feb} / 91$ & USAir & Los Angeles & B-737 & 89 & 22 \\
\hline 18. $11 / \mathrm{Jul} / 91$ & Nationair & Jeddah & DC-8 & 261 & 261 \\
\hline 19. 30/Jul/92 & TWA & New York & L-1011 & 292 & 0 \\
\hline $20.21 / \mathrm{Dec} / 92$ & Martinair & Faro, Portugal & DC- 10 & 340 & 56 \\
\hline
\end{tabular}

TABLE 2

Accidents Discussed in this Paper and the Reason for their Inclusion

\begin{tabular}{|l|l|}
\hline $\begin{array}{l}\text { CARRIER AND TYPE } \\
\text { OF AIRCRAFT }\end{array}$ & \multicolumn{1}{c|}{ REASON FOR INCLUSION } \\
\hline $\begin{array}{l}\text { South African Airlines } \\
\text { B-747 }\end{array}$ & $\begin{array}{l}\text { Inflight cargo fire. Rule change for class "B" cargo } \\
\text { compartments ("Combi"). }\end{array}$ \\
\hline Air France A-320 & Limited number of fatalities from such a severe crash and fire. \\
\hline Delta Airlines B-727 & $\begin{array}{l}\text { First commercial aircraft involved in a survivable accident with } \\
\text { a postcrash fire equipped with fire blocked seats. }\end{array}$ \\
\hline $\begin{array}{l}\text { Philippine Airlines } \\
\text { B-737 }\end{array}$ & $\begin{array}{l}\text { Major fuel tank explosion in the passenger cabin while } \\
\text { aircraft was on the ground. }\end{array}$ \\
\hline $\begin{array}{l}\text { Northwest Airlines } \\
\text { DC-9 }\end{array}$ & $\begin{array}{l}\text { Jet fuel fire inside cabin. The wing of another DC-9 sliced } \\
\text { into the cabin during a runway incursion accident. }\end{array}$ \\
\hline USAir B-727 & $\begin{array}{l}\text { Large postcrash fire and the release of oxygen in the aircraft } \\
\text { caused 21 fire fatalities. }\end{array}$ \\
\hline TWA L-1011 & 292 passengers and crew able to evacuate safely. \\
\hline
\end{tabular}


TABLE 3

Incidents Discussed in this Paper and the Reason for their Inclusion

\begin{tabular}{|l|l|}
\hline $\begin{array}{c}\text { CARRIER AND TYPE } \\
\text { OF AIRCRAFT }\end{array}$ & \multicolumn{1}{|c|}{ REASON FOR INCLUSION } \\
\hline Delta B-727 & $\begin{array}{l}\text { Oxygen fire while aircraft was loading passengers. Aircraft was } \\
\text { destroyed. }\end{array}$ \\
\hline America West B-737 & Hydraulic fire inflight that was not extinguished. \\
\hline LTU L-1011 & Use of combustable cleaning solvent destroyed aircraft. \\
\hline Delta L-1011 & Inflight fire over North Atlantic. \\
\hline Air India B-737 & Oxygen fire while aircraft in for maintenance. \\
\hline American DC-9 & Hazardous material cargo fire. \\
\hline SAS MD-87 & Electrical arcing caused major fire damage. \\
\hline
\end{tabular}

\section{ACCIDENTS AND INCIDENTS}

The following is an update of transport aircraft fire related accidents and important incidents for the years 1987 through 1993. Tables 2 and 3 summarize the accidents and incidents discussed.

\section{ACCIDENTS}

1. South African Airlines, November 28, 1987. ${ }^{2}$ A South African Airlines 747 "Combi" (passengers and cargo on the main deck) experienced an inflight fire while flying over the Indian Ocean. The plane crashed into the Indian Ocean and all on board were killed. Although the investigation is still ongoing, initial reports indicate a fire occurred in the class "B" main deck cargo compartment, grew out of control, and caused the destruction of the aircraft.

As a result of this accident, the FAA has issued an Airworthiness Directive that requires fire safety design and firefighting improvements in class " $\mathrm{B}$ " compartments.

2. Air France, June $26,1988 .{ }^{3,4}$ The aircraft crashed into trees while attempting a "touch and go". A fire immediately broke out and penetrated the cabin. Evacuation began shortly thereafter via the left side. The clothing on some of the passengers caught fire. Everyone on board was able to evacuate with the exception of a handicapped boy, a little girl, and a woman who had made it to an exit but, apparently, returned into the cabin to help the girl.

Fire blocked seats are credited with extending survival time and saving numerous lives.

3. Delta Airlines, August 31, 1988. A Delta Airlines 727 crashed on takeoff from the Dallas/Fort Worth Airport. The aircraft suffered severe structural damage as it slid to a stop approximately 3,000 feet from the end of the runway. The right wing was ripped from the fuselage, causing a large fuel spill; and the aft two cargo doors opened and a large section of the fuselage above and forward of the main aft cargo door was torn away. A large circumferential break also occurred just aft of the cockpit. A large fuel fire separated the aft section from the rest of the fuselage at the aft break. All but two of the fatalities were trapped 
in the aft section. The doors in that area could not be opened from inside because of the angle at which that portion of the fuselage was resting. The evacuation in the forward portion of the cabin was through the fuselage and the two left over-wing exits. It was estimated that evacuation time from aircraft stop until the last passenger was out was 4 minutes and 20 seconds. This was based on crash rescue and firefighting services recordings. There were two passengers in the forward cabin that succumbed to the effects of the fire.

This accident is of extreme interest since it was the first survivable accident involving fire following the implementation of the floor proximity and fire blocking rules. Initial indications from passenger interviews were that no one utilized the floor lighting in egress of the aircraft. That could be expected since the accident occurred during daylight and large breaks in the fuselage provided visible means out of the aircraft. From remains of the cabin materials and passenger accounts of the evacuation, it could be concluded that fire blocking seats did extend the survival time in the forward portion of the cabin. Although an exact additional escape time or added number of survivors that could be attributed to fire blocking cannot be determined, an estimate utilizing past test data was made. It was estimated 1 minute and 30 seconds of added survival time was provided in this accident due to the incorporation of fire blocking. That equated to a life savings of 37 passengers.

4. Philippine Airlines, May 11,1990. The aircraft was being towed from its stand to an area where the engines could be started. During the pre-start sequence, fuel vapor in the empty center wing tank was ignited. The resulting explosion ripped the floor open and upwards into the cabin, breaking the legs of some passengers in the process, and a fireball erupted into the cabin. The force of the explosion fractured the wing internally and fuel from the wing tanks fed back into the center section area where a very large intense fuel fire developed in the cabin.

The fuselage was intact, however, the cabin was disrupted by the explosion. All fatalities were due to the fire and explosion.

This accident points out that even with non-combustible materials in a cabin, a large internal fire can occur.

5. Northwest, December 3, 1990. A B-727 on its takeoff roll collided with the DC-9 in fog. The right wing of the B-727 penetrated the right side of the DC-9 fuselage, cutting into the flight deck and forward service door. It sliced the length of the cabin ejecting fuel from the damaged wing tip. On hitting the right hand engine of the DC-9, a fireball erupted from the rear of the aircraft, and fire traversed forward throughout the cabin.

The wing of the B-727 caused fatal blunt force trauma to the occupants of the cabin. The fire fatalities occurred in the aft tailcone area towards the ventral escape door. The operating mechanism for this door failed, and the passengers and one cabin attendant were trapped by the intense fire that had by this time developed in the cabin.

The interior fire was caused by fuel sprayed into the cabin, causing a rapidly developing cabin fire. 
6. USAir, February 1, 1991.5 A Boeing 737-300, collided with a Fairchild Metroliner while the B-737 airplane was landing on runway 27 left at Los Angeles International Airport, Los Angeles, California. The Metroliner was positioned on the same runway, at intersection 45, awaiting clearance for takeoff.

The B-737 remained largely intact as a result of the collision with the Metroliner. The fuselage belly was ripped open and the cabin floor displaced. The B-737 veered off the runway and into a building where the cockpit top and left sides were crushed.

All 10 passengers and two crew members aboard the Metroliner and 20 passengers and 2 crew members aboard the B-737 were fatally injured.

After the aircraft came to rest it quickly filled with smoke, reducing passenger visibility. Some passengers reported using the emergency floor path lighting to find the rear exit. Survival time in the aircraft was estimated to be about 90 seconds. A majority of the fatalities were found lined up at overwing exits.

The investigation revealed that the high pressure oxygen line next to the crew oxygen bottle in the lower area of the fuselage had been ruptured by the impact and that the release of oxygen into the forward cabin area had greatly accelerated the fire, sharply reducing survival time.

7. TWA, July 30, 1992. A TWA L-1011 aborted a takeoff, landed hard and ruptured a wing fuel tank. A large fuel fire engulfed the aft portion of the aircraft. Fire and smoke entered the cabin through the aft doors during the evacuation. All 292 occupants exited through 3 forward exits in approximately 2 minutes.

Additional "non-working" flight attendants aided in the evacuation.

\section{INCIDENTS}

In many cases, the difference between an accident and an incident is pure luck. The probability of the next aircraft accident having similarities to a given past incident are the same as the probability of similarities to a given past accident. It is, therefore, extremely important that all fire incidents with potential extensive damage to the aircraft or life-threatening be investigated, analyzed, and understood. It should be noted that because of the limited damage in some incidents much more information can be learned than in an accident. The following are examples of incidents that have led to research and/or safety improvements in aircraft:

1. Delta, Salt Lake City. Maintenance was being performed on the oxygen system in the forward electrical compartment as the aircraft was being pre boarded by passengers. As the B-727 aircraft was being reactivated a violent fire erupted. Smoke and fire quickly spread up into the first class area of the aircraft. The few passengers on board were quickly led out of the aft of the aircraft by flight attendants. The flight engineer was the last evacuee and was forced to crawl to escape the smoke and heat. He exited and overwing hatch. The estimated survival time was 30 to 45 seconds. The oxygen fed fire destroyed the aircraft. 
2. American West, Tucson. A B-737 experienced hydraulic problems inflight. The aircraft made an emergency landing and then lost all hydraulic power. The investigation showed that a frayed electrical cable had arced to a hydraulic line causing a small hole in the line. The hydraulic fire mist was ignited by the arc and continued to burn. The subsequent fire ruptured a return line on the hydraulic system and shorted the wiring to the standby pipe.

Subsequent testing showed that fire resistant hydraulic fluid mist may continue to burn after the ignition is removed if the misting occurs in a confined area.

3. LTU, Dusseldorf, Germany. While performing maintenance on the L-1011 aircraft in a hangar the vapors from a cleaning solvent ignited. The aircraft was totally destroyed by the fire.

It was discovered that the propellant for the non-combustible solvent was a replacement for the chlorofluorocarbon (CFC) and was highly inflammable.

4. Delta, North Atlantic. An inflight fire occurred in an L-1011 while on a flight over the North Atlantic. Flames were seen coming from a floor grill near the left aft end of the cabin. Flight attendants used 3 halon and one water extinguisher to extinguish the fire.

Examination of the area showed considerable burn damage; however, it was localized because the fire was extinguished before it could spread. The return air grill, some interior sidewall paneling, several square feet of the cabin floor, and insulation blankets above and below the cabin floor level were severely burn damaged. A passenger's coat that was placed on the floor caught fire as did a few smaller personal items. Beneath the cabin floor the main generator cables from the auxiliary power unit were also severely burn damaged. The cargo liner sidewall and ceiling panel in the area showed signs of fire with some of the resin burnt out and the panels sooted on the outside.

It should be noted that the original Nomex cargo liners had been replaced by fiberglass liners meeting the oil burner requirements. Had the liners been Nomex, it is probable that the fire would have burnt "over" through into the $\mathrm{C} 3$ cargo compartment.

This incident points out the need for extinguishing agents capable of penetrating into hidden areas and extinguishing inaccessible fires.

5. Indian Airlines, New Delhi, India. During maintenance of a B-737, the passenger oxygen system was deployed for a check, and an oxygen fed fire erupted in the vicinity of the pressure controller. The fire was controlled after doing structural damage to the aircraft with the use of outside fire extinguishers.

6. American Airlines, Nashville. An inflight cargo fire occurred in a DC-9 due to the carriage of hazardous materials. This incident points out the potential problem of the carriage of unlawful hazardous materials in cargo bays.

7. SAS MD-87, Copenhagen, Denmark. Just after touch down, a flight attendant in the aft of the aircraft noticed ceiling work lights in the galley area getting very bright and then go out. This was followed by an electrical smell and then white smoke from the ceiling area. As the 
aircraft pulled to the gate, black smoke began to fill the aft portion of the aircraft. Passengers were evacuated and a fire developed and spread rapidly. The fire damage was extensive in the aft of the aircraft, including burning a hole through the fuselage skin. The incident is still under investigation; however, preliminary findings indicate two wires shorted to each other and ground causing an arc which started the fire.

\section{THE FUTURE OF AIRCRAFT FIRE SAFETY}

\section{Materials Upgrade}

Most of the material flammability upgrading to date has been aimed at the postcrash fire, a fire entering into the aircraft from a large external fuel fire and spreading on the interior cabin materials. Although there are still some areas such as the seat components, curtains, and transparent fixtures that should be studied to determine if upgrading of standards would increase safety, full scale tests on seat components have indicated that incremental changes would lead to little safety improvement. Therefore, near term, only small safety improvement could be expected from cabin material flammability upgrades for the postcrash fire scenario. Long range $\mathrm{R} \& \mathrm{D}$ will center on highly fire resistant (almost non-combustible) materials.

Although the materials in the cabin have been upgraded and fire safety greatly improved, little has been done to the materials that are the most likely to be involved in an inflight fire. These are hidden materials, materials such as behind the sidwall, over the ceiling, and below the floor.

Full scale tests have shown the presently used thermal acoustic insulation does not spread a small in-flight fire on its own. However, when a small amount of contamination in applied, such as oil, grease, lint, etc., the insulation blankets can become involved. That has been the case in actual inflight fire incidents.

Wire and cable have been the source of a number of inflight smoke and fire problems. At present the only requirement is a Bunsen burner test for flammability. Work by FAA is presently underway to upgrade that requirement and to develop meaningful smoke and arc tracking requirements.

\section{Burnthrough Requirements}

In some accidents, British Airtours 737, Manchester, United Kingdom, August 22, 1986, for example, it was determined by the investigators that the external fire entered into the cabin by burning or melting through the fuselage. FAA is conducting full-scale tests to determine the modes of hazard entry into an aircraft cabin from an external fuel fire. Work to date indicates the most vulnerable area is the lower quadrant in areas with little or no thermal acoustic insulation. Initial hazard entry into the cabin is smoke, followed by flames through the air retum grills at the cabin floor level. A multinational program is now being organized to develop a test method to evaluate fuselage burnthrough improvements. 
A major step has been taken in upgrading material standards, but further improvements in that area will not solve the entire problem (cabin furnishings do not affect the smoke, heat and flames entering the cabin from the external fuel fire). Also, there are potential fire hazards from other fuel sources on board, such as hydraulic fluid, passenger carry-on materials, and oxygen. What can be done to further improve fire survivability? Have we gone far enough?

Examination of past accidents and full scale testing suggests that improvement to oxygen and hydraulic systems could improve both inflight and postcrash fire safety. Oxygen systems have been the cause of aircraft fires (ATA DC-10 in Chicago, August 1986, and Delta 727 in Salt Lake City, October 1989) and have contributed to the severity of postcrash fires (USAir 737 in Los Angeles, February 1991). For the near term, methods of containment (such as flow restrictors, fuses, or solid oxygen generating systems) should be explored. The final answer may be an oxygen nitrogen separation system. These systems (OBOGS - Onboard Oxygen Generating System) are presently available, however, with an extreme weight penalty. Long term $R \& D$ is needed to reduce the weight output ratio.

Hydraulic fluid has also contributed to both postcrash (Korean Airlines 747, Seoul, November 1980) and inflight (America West 737, Tucson, January 1990) fire hazards. Work should be carried out to develop non combustible hydraulic fluids that meet the requirements of the transport airline industry.

Even with the improvements to present systems there is still the problem of the fuel fire. How can the hazards of the external fuel fire spreading into the passenger cabin be reduced? One method that is presently being studied and shows great promise is a cabin water spray system. The idea was popularized by a company called "SAVE" in the United Kingdom. The system would consist of a fixed quantity of water stored on board the aircraft that would be discharged from nozzles throughout the cabin in the event of a postcrash fire. Testing has shown the system to be extremely effective, reducing the hazards in a cabin and extending survival time for most postcrash fire scenarios. Work to optimize the system has reduced the quantity of water needed to provide protection on aircraft the size of a 737 from 75 gallons to approximately 8 . Work is presently underway to design and cost a system for possible installation into an operational airplane.

\section{ADDITIONAL PROBLEMS}

With the banning of ozone depleting CFC's, additional problems are developing in the aircraft industry. Those problems are two-fold. First, CFC's are no longer being used as propellants in aerosol cans. The replacement propellants are butane and propane, which are highly flammable. This presents a major problem in cargo compartment fire protection. Solutions are to redesign some cargo compartments or redesign aerosol cans. Second, the halon extinguishing agents used in transport aircraft are also ozone-depleting chemicals and will no longer be manufactured, by international agreement after 1993. There is a need to effectively recycle halons and to develop new non-ozone depleting agents and the means of demonstrating equivalent fire protection to the halons in aircraft applications. 


\section{CONCLUSION}

There are still major improvements that can be made in aircraft fire safety; however, a systems approach is needed to accomplish them.

\section{REFERENCES}

1. Hill, Richard G., "Investigation and Characteristics of Major Fire Related Accidents in Civil Air Transports Over the Past Ten Years", AGARD-Conference Proceedings No. 467.

2. AD 93-07-15, Federal Register, April 20, 1993.

3. Flight International 11.17, April 1990.

4. NTSB-Report \#91/08. 